\title{
Postoperative Air Leaks with Prompt Improvement of Low Suction on Digital Drainage Devices: A Retrospective Study
}

\section{Suguru Mitsui}

Akashi Iryo Center https://orcid.org/0000-0001-9262-8441

Shunsuke Tauchi ( $\nabla$ s-tauchi@amc1.jp )

Akashi Medical Center, 743-33 Okubocho Yagi, Akashi, Hyogo, 674-0063, Japan

\section{Takahiro Uchida}

Akashi Medical Center: Akashi Iryo Center

Hisashi Ohnishi

Akashi Medical Center: Akashi Iryo Center

\section{Toshio Shimokawa}

Wakayama Kenritsu Ika Daigaku

\section{Satoshi Tobe}

Akashi Medical Center: Akashi Iryo Center

\section{Research article}

Keywords: Prolonged air leaks, Chest drain, Lung cancer, Low-pressure suction, Digital drainage system

Posted Date: November 2nd, 2020

DOl: https://doi.org/10.21203/rs.3.rs-99705/v1

License: (1) This work is licensed under a Creative Commons Attribution 4.0 International License. Read Full License 


\section{Abstract}

Purpose: The aim was to investigate the most effective suction pressure for preventing or promptly improving postoperative air leaks.

Methods: We retrospectively analyzed the postoperative data of 242 patients who were monitored with a digital drainage system after pulmonary resection between December 2017 and June 2020. We divided the patients into 3 of group by suction pressure, A (Low-pressure suction group: $-5 \mathrm{~cm} \mathrm{H \otimes O}$ ), B (Intermediate-pressure group: $-10 \mathrm{~cm} \mathrm{HखO),} \mathrm{C} \mathrm{(High-pressure} \mathrm{suction} \mathrm{group:}-20 \mathrm{~cm} \mathrm{H \otimes O)}$ ). Duration of air leaks, duration of chest tube replacement, the amount of postoperative air leak, fluid volume drained before chest tube removal, and the maximum amount of air leaks during drainage were evaluated.

Results: A total 217 patients were included. In the order of A, B, and C groups, duration of air leaks gradually decreased and significant trend was observed $(p=0.019)$. Duration of chest tube replacement did not significantly differ among the three groups $(p=0.126)$. The amount of postoperative air leak just after surgery did not significantly differ among the three groups $(p=0.175)$, however, the amount of postoperative day 1 air leak gradually decreased with statistical significance in order of $A, B$, and $C$ groups ( $p=0.033$ ). The maximum amount of air leaks during drainage gradually decreased in order of $A, B$ and $\mathrm{C}$ groups $(p=0.036)$. Fluid volume drained before chest tube removal did not significantly differ among the three groups $(p=0.986)$.

Conclusion: Low-pressure suction after pulmonary resection would be useful for preventing or promptly improving postoperative air leaks.

\section{Introduction}

A postoperative air leak after pulmonary resection is one of the major factors that prevent leaving bed and delay early hospital discharge. Chest tube is critical component for postoperative air leakage management and affect hospital stay and costs $(1,2)$. Moreover, the removal of chest tube reduces pain and improves ventilatory function in early postoperative course (3). Chest drainage tubes are routinely placed in the pleural space in order to promote re-expansion and evaluate postoperative air leak and bleeding after pulmonary resection. There are many studies examining the optimum chest tube management for postoperative air leak after pulmonary resection. Several reports suggested that chest tube drainage followed by water seal could reduce duration of air leak and chest tube replacement after pulmonary resection $(4,5)$. In recent years, with the advent of the digitally monitored thoracic system (Medela, Healthcare, Baar, Switzerland), quantitative and temporal evaluations of postoperative air leakage and pleural pressure after pulmonary resection became possible. We hypothesized that low negative pressure suction on the chest tube after pulmonary resection could shorten duration of air leakage and chest tube replacement. The purpose of this study was to quantitative and temporal evaluate which suction pressure is most effective in preventing or early improving postoperative air leakage by the use of digitally monitored thoracic system. 


\section{Material And Methods}

We investigate the most effective suction pressure for preventing or promptly improving postoperative air leaks. This is a single-institution, retrospective analysis-based study of data from an electronic database. Study protocol was approved by the Akashi Medical Center Institutional Research Ethics Board (approval number: 2020-9).

\section{Patient Data}

We collected the postoperative data of 242 patients who were monitored with a digital drainage system (Thopaz, Medela, Inc, Baar, Switzerland) after pulmonary resection. Included were patients who had lung resection using this digital drainage system between December 2017 and June 2020. We changed the suction pressure depending on periods. We divided the patients into 3 of suction group by observation period, A (Low-pressure suction group: -5 cm H囚O) between October 2019 and June 2020, B (Intermediatepressure group: -10 cm HखO) between May 2018 and October 2019, C (High-pressure suction group: $-20 \mathrm{~cm} \mathrm{H} \otimes$ O) between December 2017 and May 2018. We excluded patients who had reoperation, those with re-drainage, those with pleurodesis after surgery, and any patients that died perioperatively. Patients treated by re-drainage or pleurodesis were excluded because they would have remained in the study for a long period of time owing to chest tube replacement time, and their data would have limited clinical relevance to the outcomes.

\section{Intervention}

Patients underwent lobectomy, segmentectomy, and wedge resection for benign and neoplastic diseases. Surgery was performed by video assisted thoracoscopic surgery (VATS) and posterolateral thoracotomy. Before closing a surgical incision, a sealing test was performed. The methods of sealing air leaks was managed with soft coagulation system. Additionally, we covered stapler line and bronchial stump with polyglycolic acid sheets and fibrin glue to prevent further air leaks in patients undergoing lobectomy or segmentectomy. One chest tube (18-20 Fr) was inserted before closure of the chest. After the surgery, the digital drainage system (Thopaz) was connected. The suction pressure in each group was set as follows:

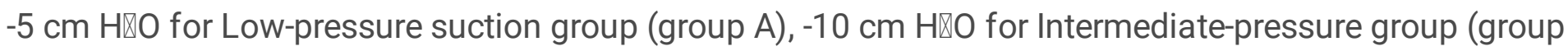
B) or $-20 \mathrm{~cm} \mathrm{H \otimes O}$ for High-pressure suction group (group C) immediately after the operation until removal of the chest tube. The chest tube was removed when an air leak was $<20 \mathrm{ml} / \mathrm{min}$ and there were no spikes for at least 8 hours, and when the fluid drainage was $<200 \mathrm{ml}$ over $24 \mathrm{~h}$. In patients undergoing lobectomy or segmentectomy, chest tubes were removed after at least two postoperative days. Clinical outcomes were duration of air leaks, duration of chest tube replacement, the amount of one-day postoperative air leak, fluid volume drained before chest tube removal, and the maximum amount of air leaks during drainage. We analyzed clinical outcomes with ThopEasy software (Thopaz, Medela, Inc, Baar, Switzerland). 


\section{Statistical analysis}

Demographic characteristics of the patients were described using the mean with standard deviation (SD) for continuous variables and the frequency with proportion for categorical cariables. The Kruskal-Wallis test was used to compare the continuous outcomes, and Wilcoxon test with Holm adjustment was used to compare the three group pairwise. Moreover, to assess the trends of the chest and outcomes, we performed Jonckheere-Terpatra trend tests. All statistical analysis were performed with EZR software version 1.40 (Saitama, Medical Center, Jichi Medical University, Saitama, Japan), a graphical user interface for R (The R Foundation for Stastistical Computing, Vienna, Austria) (6). A p value $<0.05$ was considered statistically significant.

\section{Results}

We analyzed data from 242 consecutive patients who were digitally monitored by Thopaz system after undergoing pulmonary resection during the study period (Fig. 1). Patient characteristics and operative data are presented in Table 1. Of these patients, 25 met the exclusion criteria; nine patients underwent reoperation because of postoperative air leaks $(n=7)$ or bleeding $(n=2)$, thirteen patients required pleurodesis, and two patients treated by re-drainage needed additional thoracostomy because of severe subcutaneous emphysema leading to lung expansion failure after surgery. One patient died of perioperative cardiac disease. 
Table 1

Patient characteristics and operative data

\begin{tabular}{|c|c|c|c|}
\hline \multirow[t]{4}{*}{ Characteristics } & \multicolumn{3}{|c|}{ No. $(\%)(n=217)$} \\
\hline & $\begin{array}{l}\text { Low-pressure } \\
\text { suction }\end{array}$ & $\begin{array}{l}\text { Intermediate-pressure } \\
\text { suction }\end{array}$ & $\begin{array}{l}\text { High-pressure } \\
\text { suction }\end{array}$ \\
\hline & $(n=49)$ & $(n=100)$ & $(n=68)$ \\
\hline & Group A & Group B & Group C \\
\hline Sex (males/females) & $37 / 12$ & $73 / 27$ & $46 / 22$ \\
\hline Age $($ mean \pm SD $)$ & $63.7 \pm 19.1$ & $54.8 \pm 24.2$ & $58.2 \pm 20.9$ \\
\hline \multicolumn{4}{|l|}{ Primary disease } \\
\hline Lung Cancer & 28 & 47 & 31 \\
\hline Metastatic Cancer & 4 & 2 & 3 \\
\hline Pneumothorax & 14 & 38 & 27 \\
\hline Others & 3 & 13 & 7 \\
\hline \multicolumn{4}{|l|}{ Comorbidities } \\
\hline Emphysema & 8 & 9 & 7 \\
\hline $\begin{array}{l}\text { Interstitial } \\
\text { pneumonia }\end{array}$ & 2 & 4 & 2 \\
\hline Diabetes mellitus & 5 & 9 & 3 \\
\hline VATS & $48(98)$ & $94(94)$ & $66(97)$ \\
\hline \multicolumn{4}{|l|}{ Surgical procedure } \\
\hline Anatomical resection & $29(59)$ & $47(47)$ & $34(50)$ \\
\hline Wedge resection & $20(41)$ & $53(53)$ & $34(50)$ \\
\hline
\end{tabular}

Patients comprised 156 men and 61 women with ages ranging between 14 and 94 years (median 58 years). The most common diagnosis was primary lung cancer $(n=106)$, followed by pneumothorax $(n$ $=79)$, and lung metastases $(n=9)$. Anatomical pulmonary resection was reported in 110 patients $(51 \%)$. Operations included 110 anatomical resections, and 107 wedge resections.

Group A (Low-pressure suction group: $-5 \mathrm{~cm} \mathrm{H} \mathbb{\mathrm { O }}$ suction group) comprised 49 patients (25 underwent lobectomy, 4 underwent segmentectomy, 20 wedge resection). Of these patients, three met the exclusion criteria (1 underwent reoperation, 1 required pleurodesis, 1 died). Group B (Intermediate-pressure group: $-10 \mathrm{~cm} \mathrm{H \otimes O} \mathrm{suction} \mathrm{group)} \mathrm{comprised} 100$ patients (30 underwent lobectomy, 17 underwent 
segmentectomy, 53 wedge resection). Of these patients, sixteen met exclusion criteria (7 underwent reoperation, 7 required pleurodesis, 2 required re-drainage). Group C (High-pressure group: $-20 \mathrm{~cm} \mathrm{H \otimes O}$ suction group) comprised 68 patients (30 underwent lobectomy, 4 underwent segmentectomy, 34 wedge resection). Of these patients, six met exclusion criteria ( 1 underwent reoperation, 5 required pleurodesis). Patient characteristics were not distributed evenly. There were no statistically significant differences between the groups in terms of sex, age, primary disease, comorbidities, VATS, or surgical procedures. An intraoperative air leak was observed in 87 patients (40\%). The number of patients with intraoperative air leak was 22 in group A (45\%), 36 in group B (36\%), and 29 in group C (43\%). A postoperative air leak was observed in 56 patients (26\%). The number of patients with postoperative air leak was 8 in group $A$ $(16.3 \%), 24$ in group B (24\%), and 24 in group C (35\%).

Clinical outcomes are presented in Table 2. Assessment of air leaks of patients was performed every morning. The mean duration of air leaks was 0.57 days in group $A, 0.78$ days in group $B$, and 1.13 days in group $C$. In the order of $A, B$, and $C$ groups, duration of air leaks gradually decreased and significant trend was observed ( $p=0.019$ by the Jonckheere-Terpstra test). This analysis indicates that chest tube suction pressure was significantly associated with duration of air leaks and low suction pressure promptly improves postoperative air leaks. However, the mean duration of chest tube replacement was 2.12 days in group $A, 2.17$ days in group $B$, and 2.35 days in group $C$ and did not significantly differ among the three groups ( $p=0.126$ by the Jonckheere-Terpstra test). The amount of postoperative day 1 air leak gradually decreased with statistical significance in order of $\mathrm{A}, \mathrm{B}$, and $\mathrm{C}$ groups $(p=0.033$ by the JonckheereTerpstra test). The amount of postoperative day 2 air leak did not significantly differ among the three groups ( $p=0.520$ by the Jonckheere-Terpstra test). The amount of postoperative air leak just after surgery did not significantly differ among the three groups ( $p=0.175$ by the Jonckheere-Terpstra test). The maximum amount of air leaks during drainage gradually decreased in order of $A, B$ and $C$ groups ( $p$ $=0.036$ by the Jonckheere-Terpstra test). The mean fluid volume drained before chest tube removal was $304.5 \mathrm{~mL}$ in group $\mathrm{A}, 289.7 \mathrm{~mL}$ in group $\mathrm{B}$, and $289.0 \mathrm{~mL}$ in group $\mathrm{C}$. Fluid volume drained before chest tube removal did not significantly differ between among three groups $(p=0.986$ by the JonckheereTerpstra test). 
Table 2

Clinical outcomes

\begin{tabular}{|c|c|c|c|c|c|c|c|}
\hline \multirow[t]{2}{*}{ Clinical Outcome } & \multirow{2}{*}{$\begin{array}{l}\text { Low } \\
\text { Pressure } \\
\text { Group A }\end{array}$} & \multirow{2}{*}{$\begin{array}{l}\text { Intermediate } \\
\text { Pressure } \\
\text { Group B }\end{array}$} & \multirow{2}{*}{$\begin{array}{l}\text { High } \\
\text { Pressure } \\
\text { Group C }\end{array}$} & \multicolumn{3}{|c|}{$\begin{array}{l}P \text { value (difference } \\
\text { between groups) }\end{array}$} & \multirow{2}{*}{$\begin{array}{l}\text { Pvalue } \\
\text { (Jonckheere- } \\
\text { Terpstra } \\
\text { test } \\
\text { statistics) }\end{array}$} \\
\hline & & & & $\begin{array}{l}\text { Avs } \\
B\end{array}$ & $\begin{array}{l}\text { Avs } \\
\text { C }\end{array}$ & $\begin{array}{l}\text { B vs } \\
\text { C }\end{array}$ & \\
\hline $\begin{array}{l}\text { Duration of air } \\
\text { leaks, d }\end{array}$ & $\begin{array}{l}0.57 \pm \\
1.60\end{array}$ & $0.78 \pm 1.65$ & $\begin{array}{l}1.13 \pm \\
1.70\end{array}$ & 0.297 & 0.016 & 0.055 & 0.019 \\
\hline $\begin{array}{l}\text { Duration of chest } \\
\text { tube replacement, } \\
d\end{array}$ & $\begin{array}{l}2.12 \pm \\
1.78\end{array}$ & $2.17 \pm 1.66$ & $\begin{array}{l}2.35 \pm \\
1.67\end{array}$ & 0.730 & 0.380 & 0.380 & 0.126 \\
\hline $\begin{array}{l}\text { Postoperative air } \\
\text { leak, } \mathrm{mL} / \mathrm{min}\end{array}$ & $\begin{array}{l}15.71 \pm \\
48.18\end{array}$ & $6.00 \pm 12.87$ & $\begin{array}{l}22.50 \pm \\
78.92\end{array}$ & 0.454 & 0.089 & 0.110 & 0.060 \\
\hline $\begin{array}{l}\text { Postoperative } 1 \text { st } \\
\text { day air leak, } \\
\mathrm{mL} / \mathrm{min}\end{array}$ & $\begin{array}{l}7.76 \pm \\
28.00\end{array}$ & $3.40 \pm 8.31$ & $\begin{array}{l}8.53 \pm \\
16.41\end{array}$ & 0.353 & 0.035 & 0.041 & 0.033 \\
\hline $\begin{array}{l}\text { Postoperative 2nd } \\
\text { day air leak, } \\
\mathrm{mL} / \mathrm{min}\end{array}$ & $\begin{array}{l}7.59 \pm \\
23.55\end{array}$ & $3.12 \pm 8.15$ & $\begin{array}{l}8.40 \pm \\
29.51\end{array}$ & 0.980 & 0.980 & 0.980 & 0.520 \\
\hline $\begin{array}{l}\text { Maximum air } \\
\text { leaks, } \mathrm{mL} / \mathrm{min}\end{array}$ & $\begin{array}{l}16.94 \pm \\
49.04\end{array}$ & $7.20 \pm 16.09$ & $\begin{array}{l}27.06 \pm \\
81.77\end{array}$ & 0.507 & 0.059 & 0.059 & 0.031 \\
\hline Fluid volume, $\mathrm{mL}$ & $\begin{array}{l}304.5 \pm \\
356.6\end{array}$ & $\begin{array}{l}289.7 \pm \\
295.0\end{array}$ & $\begin{array}{l}289.0 \pm \\
280.1\end{array}$ & 1.000 & 1.000 & 1.000 & 0.986 \\
\hline
\end{tabular}

Clinical outcome in patients who underwent anatomical resection are presented in Table 3. The mean duration of air leaks was 0.90 days in group $A, 1.55$ days in group $B$, and 1.94 days in group $C$. In the order of $A, B$, and $C$ groups, duration of air leaks gradually decreased with statistical significance $(p=$ 0.010 by the Jonckheere-Terpstra test). The mean duration of chest tube replacement was 2.72 days in group $A, 3.10$ days in group $B$, and 3.15 days in group $C$ and did not significantly differ among the three groups ( $p=0.141$ by the Jonckheere-Terpstra test). The amount of postoperative air leaks just after surgery and postoperative day 1 gradually decreased with statistical significance in order of $A, B$, and $C$ groups ( $p=0.017$ and 0.008 by the Jonckheere-Terpstra test). The amount of postoperative day 2 air leak did not significantly differ among the three groups ( $p=0.389$ by the Jonckheere-Terpstra test). The maximum amount of air leaks during drainage decreased in order of $A, B$ and $C$ groups $(p=0.010$ by the Jonckheere-Terpstra test). The mean fluid volume drained before chest tube removal was $424.6 \mathrm{~mL}$ in 
group A, $459.3 \mathrm{~mL}$ in group $B$, and $477.7 \mathrm{~mL}$ in group $\mathrm{C}$. Fluid volume drained before chest tube removal did not significantly differ between the three groups ( $p=0.288$ by the Jonckheere-Terpstra test).

Table 3

Clinical outcomes (anatomical resection)

\begin{tabular}{|c|c|c|c|c|c|c|c|}
\hline \multirow[t]{2}{*}{ Clinical Outcome } & \multirow{2}{*}{$\begin{array}{l}\text { Low } \\
\text { Pressure } \\
\text { Group A }\end{array}$} & \multirow{2}{*}{$\begin{array}{l}\text { Intermediate } \\
\text { Pressure } \\
\text { Group B }\end{array}$} & \multirow{2}{*}{$\begin{array}{l}\text { High } \\
\text { Pressure } \\
\text { Group C }\end{array}$} & \multicolumn{3}{|c|}{$\begin{array}{l}P \text { value (difference } \\
\text { between groups) }\end{array}$} & \multirow{2}{*}{$\begin{array}{l}\text { Pvalue } \\
\text { (Jonckheere- } \\
\text { Terpstra } \\
\text { test } \\
\text { statistics) }\end{array}$} \\
\hline & & & & $\begin{array}{l}\text { Avs } \\
B\end{array}$ & $\begin{array}{l}\text { Avs } \\
\text { C }\end{array}$ & $\begin{array}{l}\text { B vs } \\
\text { C }\end{array}$ & \\
\hline $\begin{array}{l}\text { Duration of air } \\
\text { leaks, } d\end{array}$ & $\begin{array}{l}0.90 \pm \\
2.00\end{array}$ & $1.55 \pm 2.13$ & $\begin{array}{l}1.94 \pm \\
1.98\end{array}$ & 0.175 & 0.009 & 0.194 & 0.010 \\
\hline $\begin{array}{l}\text { Duration of chest } \\
\text { tube replacement, } \\
\text { d }\end{array}$ & $\begin{array}{l}2.72 \pm \\
2.03\end{array}$ & $3.10 \pm 2.00$ & $\begin{array}{l}3.15 \pm \\
1.96\end{array}$ & 0.580 & 0.250 & 0.580 & 0.141 \\
\hline $\begin{array}{l}\text { Postoperative air } \\
\text { leak, } \mathrm{mL} / \mathrm{min}\end{array}$ & $\begin{array}{l}26.20 \pm \\
60.79\end{array}$ & $8.51 \pm 12.15$ & $\begin{array}{l}42.94 \pm \\
108.36\end{array}$ & 0.467 & 0.061 & 0.061 & 0.017 \\
\hline $\begin{array}{l}\text { Postoperative 1st } \\
\text { day air leak, } \\
\mathrm{mL} / \mathrm{min}\end{array}$ & $\begin{array}{l}12.76 \pm \\
35.75\end{array}$ & $6.81 \pm 11.05$ & $\begin{array}{l}15.59 \pm \\
20.63\end{array}$ & 0.160 & 0.019 & 0.082 & 0.008 \\
\hline $\begin{array}{l}\text { Postoperative 2nd } \\
\text { day air leak, } \\
\mathrm{mL} / \mathrm{min}\end{array}$ & $\begin{array}{l}8.46 \pm \\
24.77\end{array}$ & $5.22 \pm 10.05$ & $\begin{array}{l}12.06 \pm \\
35.31\end{array}$ & 0.830 & 0.790 & 0.830 & 0.389 \\
\hline $\begin{array}{l}\text { Maximum air } \\
\text { leaks, } \mathrm{mL} / \mathrm{min}\end{array}$ & $\begin{array}{l}28.28 \pm \\
61.59\end{array}$ & $8.93 \pm 12.55$ & $\begin{array}{l}51.18 \pm \\
111.02\end{array}$ & 0.647 & 0.043 & 0.020 & 0.010 \\
\hline Fluid volume, $\mathrm{mL}$ & $\begin{array}{l}424.6 \pm \\
413.5\end{array}$ & $\begin{array}{l}459.3 \pm \\
349.0\end{array}$ & $\begin{array}{l}477.7 \pm \\
354.8\end{array}$ & 0.940 & 0.940 & 0.940 & 0.288 \\
\hline
\end{tabular}

Clinical outcome in patients who underwent wedge resection are presented in Table 4. All category did not significantly differ among the three groups. 
Table 4

Clinical outcomes (wedge resection)

\begin{tabular}{|c|c|c|c|c|c|c|c|}
\hline \multirow[t]{2}{*}{ Clinical Outcome } & \multirow{2}{*}{$\begin{array}{l}\text { Low } \\
\text { Pressure } \\
\text { Group A }\end{array}$} & \multirow{2}{*}{$\begin{array}{l}\text { Intermediate } \\
\text { Pressure } \\
\text { Group B }\end{array}$} & \multirow{2}{*}{$\begin{array}{l}\text { High } \\
\text { Pressure } \\
\text { Group C }\end{array}$} & \multicolumn{3}{|c|}{$\begin{array}{l}P \text { value (difference } \\
\text { between groups) }\end{array}$} & \multirow{2}{*}{$\begin{array}{l}P \text { value } \\
\text { (Jonckheere- } \\
\text { Terpstra } \\
\text { test } \\
\text { statistics) }\end{array}$} \\
\hline & & & & $\begin{array}{l}\text { A vs } \\
B\end{array}$ & $\begin{array}{l}\text { Avs } \\
\text { C }\end{array}$ & $\begin{array}{l}\text { B vs } \\
\text { C }\end{array}$ & \\
\hline $\begin{array}{l}\text { Duration of air } \\
\text { leaks, d }\end{array}$ & $\begin{array}{l}0.10 \pm \\
0.45\end{array}$ & $0.09 \pm 0.40$ & $\begin{array}{l}0.32 \pm \\
0.77\end{array}$ & 0.940 & 0.390 & 0.220 & 0.363 \\
\hline $\begin{array}{l}\text { Duration of chest } \\
\text { tube replacement, } \\
d\end{array}$ & $\begin{array}{l}1.25 \pm \\
0.72\end{array}$ & $1.36 \pm 0.52$ & $\begin{array}{l}1.56 \pm \\
0.75\end{array}$ & 0.300 & 0.120 & 0.300 & 0.079 \\
\hline $\begin{array}{l}\text { Postoperative air } \\
\text { leak, } \mathrm{mL} / \mathrm{min}\end{array}$ & $\begin{array}{l}0.50 \pm \\
2.24\end{array}$ & $3.77 \pm 13.19$ & $\begin{array}{l}2.06 \pm \\
6.40\end{array}$ & 1.000 & 1.00 & 1.00 & 0.706 \\
\hline $\begin{array}{l}\text { Postoperative } 1 \mathrm{st} \\
\text { day air leak, } \\
\mathrm{mL} / \mathrm{min}\end{array}$ & $\begin{array}{l}0.50 \pm \\
2.24\end{array}$ & $0.38 \pm 1.92$ & $\begin{array}{l}1.47 \pm \\
4.36\end{array}$ & 0.830 & 0.820 & 0.450 & 0.596 \\
\hline $\begin{array}{l}\text { Postoperative } \\
\text { 2nd day air leak, } \\
\mathrm{mL} / \mathrm{min}\end{array}$ & - & - & - & - & - & - & - \\
\hline $\begin{array}{l}\text { Maximum air } \\
\text { leaks, } \mathrm{mL} / \mathrm{min}\end{array}$ & $\begin{array}{l}0.50 \pm \\
2.24\end{array}$ & $5.66 \pm 18.66$ & $\begin{array}{l}2.94 \pm \\
7.19\end{array}$ & 0.770 & 0.530 & 0.770 & 0.466 \\
\hline Fluid volume, $\mathrm{mL}$ & $\begin{array}{l}130.35 \\
\pm 123.86\end{array}$ & $\begin{array}{l}169.88 \pm \\
173.06\end{array}$ & $\begin{array}{l}136.19 \\
\pm 119.56\end{array}$ & 1.000 & 1.00 & 1.000 & 1.000 \\
\hline $\begin{array}{l}\text { Postoperative air l } \\
\text { maximum amount } \\
\text { removal. }\end{array}$ & $\begin{array}{l}\text { Postope } \\
\text { air leaks }\end{array}$ & $\begin{array}{l}\text { ive air leak im } \\
\text { ing drainage. }\end{array}$ & $\begin{array}{l}\text { ediately a } \\
\text { uid volum }\end{array}$ & $\begin{array}{l}\text { er surg } \\
\text { F Fluid }\end{array}$ & $\begin{array}{l}\text { Maxir } \\
\text { ume d }\end{array}$ & $\begin{array}{l}\text { m air le } \\
\text { hed bef }\end{array}$ & $\begin{array}{l}\text { iks: the } \\
\text { re chest tube }\end{array}$ \\
\hline
\end{tabular}

\section{Discussion}

A postoperative air leaks after pulmonary resection is one of the major factors in the cooperative period. Generally, postoperative air leakage stops spontaneously after a few hours up to few days $(4,5,7)$. However, prolonged air leaks can cause various complications such as atrial fibrillation, thromboembolism, empysema, pneumonia, and respiratory failure which lead to prolonged hospital stay and increasing costs $(1,2)$. Our predecessors have tried various approaches to chest drain management for postoperative air leaks. Alphonso and colleagues and Brunelli and colleagues have described in their randomized study on the patients who underwent pulmonary resection that there are no differences between suction group and non-suction group concerning duration of air leaks $(8,9)$. Although Leo et al, have described the routine use of external suction reduces the rate of prolonged air leaks after anatomic lung resection (10), Gocyk et al, have reported in their retrospective study that non suction drainage is 
more effective than suction drainage with regard to drainage volume, drainage duration, and the rate of prolonged air leak (5). The optimum postoperative suction pressure remains controversial.

Until recently, it is difficult to evaluate the amount of air leak by traditional closed chest tube drainage system. However, in recent years, with the advent of the digitally monitored drainage system, quantitative and temporal evaluations of postoperative air leaks and pleural pressure after pulmonary resection became possible. Goto $\mathrm{M}$, et al, have reported that digitally monitored drainage system was useful predicting postoperative air leaks after pulmonary resection (11). Additionally, digitally monitored drainage system showed a significant reduction in duration of air leaks, chest tube replacement, and hospitalization compared to traditional closed chest tube (12). The main strength of our study is that the effect of chest tube suction pressure on the postoperative air leaks was quantitatively evaluated.

In our present study, it became so clear that duration of air leaks tends to be short significant as the suction pressure has decreased. It is suggested that low-pressure suction shortened duration of air leaks. Holbek et al. report similar findings in a prospective randomized study that a low suction pressure significantly shortened duration of air leaks and chest drain replacement (13). This study supports the study above-mentioned, however, duration of chest tube replacement did not significantly differ among the three groups. This is thought to be due to the chest tube removal after at least two postoperative days in patients undergoing lobectomy or segmentectomy. In addition, low-pressure suction tends to make the amount of air leak just after surgery and on postoperative 1 day fall, while there are no significant difference on postoperative 2 day in our analysis of anatomical pulmonary resection. In concluded, we suggest that low-pressure suction at least postoperative 1 day have the possibility of early improvement of air leakage on the patients whose air leakage can be expected to stop spontaneously. Handing the lung in kind way by low-suction pressure probably cause promoting early improvement of damage of lung parenchyma and preventing new tears in lung parenchyma by keeping a lung in the rest. There is no significant difference in fluid volume drained before chest tube removal between three types of suction pressure. We believe that it is not necessary to perform high-pressure suction drainage considering postoperative pleural effusions and hemorrhage. The difference of all category between low-suction pressure group (group A) and intermediate-suction pressure group (group B) was not clear, but there is a good possibility that more accumulation was significant due to differences in the number of cases. Clinical outcome in patients who underwent wedge resection did not significantly differ between three groups. Given the lower numbers of postoperative air leakage appeared in the patients who underwent wedge resection, this may be attributable to a lack of power.

This study has several limitations. Our retrospective study was performed without the randomization of patient selection in a single center. Patients characteristics has no significant difference in all category between three groups, however, we could not deny some sample bias could distort our result because of no randomization. In addition, the number of excluded cases has increased to 25 cases because next treatment criteria for postoperative air leakage has not been decided. In some cases, pleurodesis and surgery were performed early after surgery, and in some cases second treatment were performed after 
one week, therefore, we have no choice to exclude all cases of second treatment for postoperative air leakage and bleeding.

\section{Conclusion}

Results of this analysis indicated that low suction pressure $(-5 \mathrm{~cm} \mathrm{H} \otimes \mathrm{O})$ shortened the duration of air leaks after pulmonary resection compared to other groups $(-10 \mathrm{~cm} \mathrm{H \otimes O}$ and $-20 \mathrm{~cm} \mathrm{H \otimes O})$. In addition, fluid volume drained before chest tube removal did not significantly differ among the three groups. Lowpressure suction after pulmonary resection would be useful for preventing or promptly improving postoperative air leaks.

\section{Declarations}

\section{Acknowledgements}

We acknowledge proofreading and editing by Benjamin Phillis.

\section{Conflict of interest}

The authors have declared that they have no conflict of interest.

\section{References}

1. Okereke I, Murthy SC, Alster JM, Blackstone EH, Rice TW. Characterization and importance of air leak after lobectomy. Ann thorac Surg 2005;79:1167-73.

2. Irshad K, Feldman LS, Chu VF, Dorval JF, Baslaim G, Morin JE. Causes of increased length of hospitalization on a general thoracic surgery service: a prospective observational study. Can J Surg 2002;45:264-8.

3. Refai $M$, Brunelli A, Salati $M$, Xiumè F, Pompili C, Sabbatini A. The impact of chest tube removal on pain and pulmonary function after pulmonary resection. Eur J Cardiothorac Surg 2012;41:820-23.

4. Marshall MB, Deeb ME, Bleier JI, Kucharczuk JC, Friedberg JS, Kaiser LR, et al. Suction vs Water Seal After Pulmonary Resection: A Randomized Prospective Study. Chest 2002;121:831-5.

5. Gocyk W, Kużdżał J, Włodarczyk J, Grochowski Z, Gil T, Warmus J,et al. Comparison of Suction Versus Nonsuction Drainage After Lung Resections: A Prospective Randomized Trial. Ann Thorac Surg 2016;102:1119-24.

6. Kanda Y. Investigation of the freely-available easy-to-use software "EZR" (Easy R) for medical statistics. Bone Marrow Transplant 2013;48:452-458.

7. Mueller MR, Marzluf BA. The anticipation and management of air leaks and residual spaces post lung resection. J Thorac Dis 2014;6:271-84. 
8. Alphonso N, Tan C, Utley M, Cameron R, Dussek J, Lang-lazdunski L, et al. A prospective randomized controlled trial of suction versus non-suction to the under-water seal drains following lung resection. Eur J Cardiothorac Surg 2005;27:391-4.

9. Brunelli A, Monteverde M, Borri A, Salati M, Marasco R, Refai M, et al. Comparison of water seal and suction after pulmonary lobectomy: a prospective, randomized trial. Ann Thorac Surg 2004;77:19327.

10. Leo F, Duranti L, Girelli L, Furia S, Billè A, Garofalo G, et al. Does External Pleural Suction Reduce Prolinged Air Leak After Lung Resection? Results from the AirlNTrial After 500 Randomized Cases. Ann Thorac Surg 2013;96:1234-9.

11. Goto M, Aokage K, Sekihara K, Miyoshi T, Tane K, Yokoi K, et al. Prediction of prolonged air leak after lung resection using continuous log data of flow by digital drainage system. Gen Thoracic and Cardiovascular Surgery 2019;67:684-9

12. Takamochi K, Imashimizu K, Fukui M, Maeyashiki T, Suzuki M, Ueda T, et al. Utility of Objective Chest Tube Management After Pulmonary Resection Using a Digital Drainage System. Ann Thorac Surg 2017; 104:275-83.

13. Holbek BL, Christensen M, Hansen HJ, Kehlet H, Peterson RH. The effect of low suction on digital drainage devices after lobectomy using video-assisted thoracoscopic surgery: a randomized controlled trial. Eur J Cardiothorac Surg 2019;55:673-81.

\section{Figures}


Inclusion Criteria:

Patients who were digitally monitored with digitally monitored drainage system after pulmonary resection between December 2017 and June $2020(n=242)$.

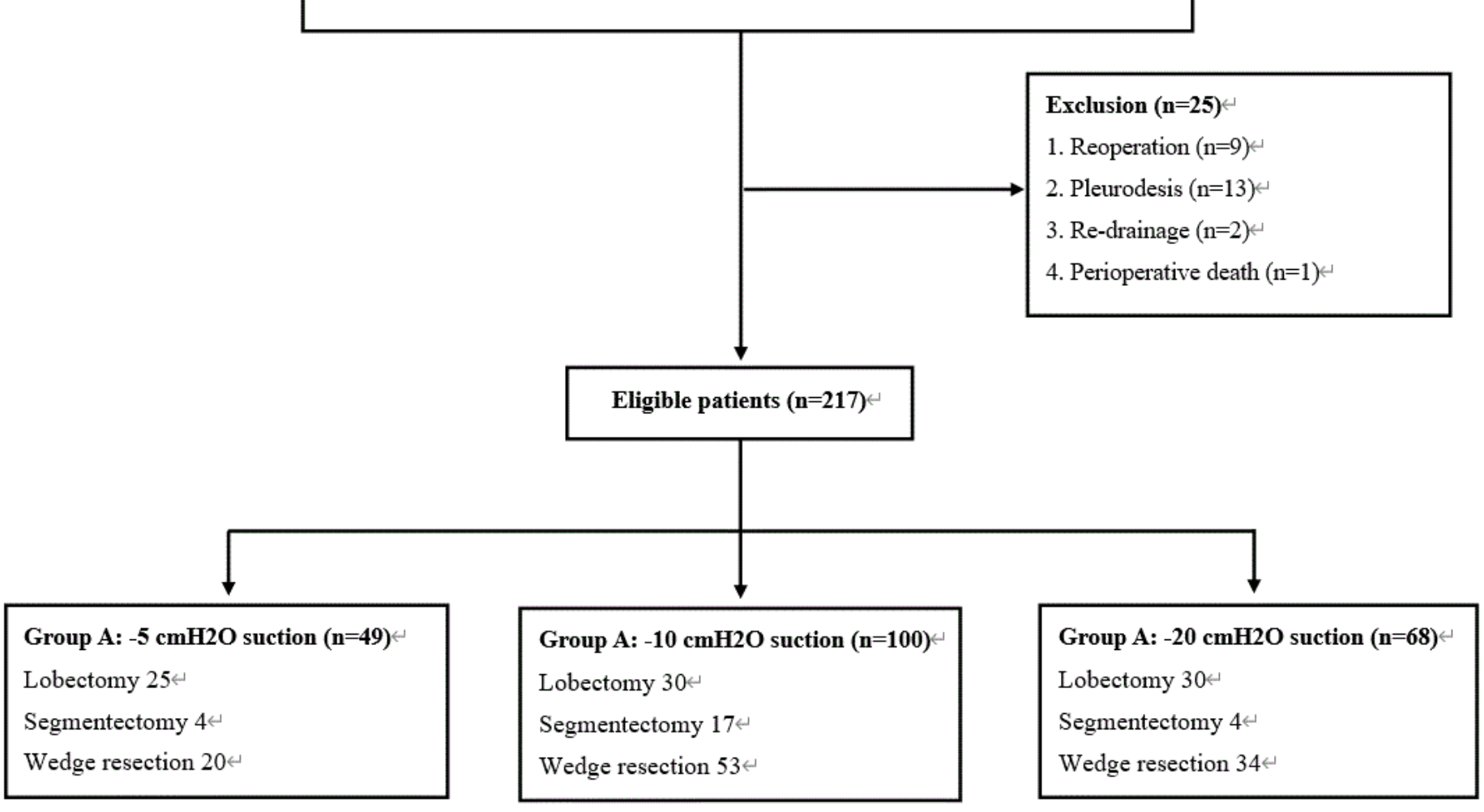

\section{Figure 1}

Patient algorism for this retrospective study. 